\begin{tabular}{|c|c|c|c|}
\hline Article Info & \multicolumn{2}{|c|}{\begin{tabular}{l|l} 
REVIEW ARTICLE & DERLEME MAKALESİ
\end{tabular}} & \\
\hline Title of Article & \multicolumn{2}{|c|}{$\begin{array}{c}\text { Evaluation of Stormwater Pollutant } \\
\text { Removal Efficiency of Bioretention Systems } \\
\text { within the Scope of Green Infrastructure } \\
\text { Applications }\end{array}$} & \\
\hline $\begin{array}{l}\text { Corresponding } \\
\text { Author }\end{array}$ & \multicolumn{2}{|c|}{$\begin{array}{l}\text { Gökçen Bayrak } \\
\text { Trakya Üniversitesi, Mimarlık Fakültesi, Peyzaj Mimarlığı Bölümü, Edirne } \\
\text { gokcenbayrak@,trakya.edu.tr }\end{array}$} & \\
\hline $\begin{array}{l}\text { Received Date } \\
\text { Accepted Date }\end{array}$ & \multicolumn{2}{|l|}{$\begin{array}{l}03.07 .2021 \\
14.09 .2021\end{array}$} & \\
\hline DOI number & \multicolumn{2}{|l|}{ https://doi.org/10.35674/kent.961967 } & \\
\hline Author / Authors & $\begin{array}{l}\text { Gökçen BAYRAK } \\
\text { Cansu KÜP }\end{array}$ & $\begin{array}{l}\text { ORCID: 0000-0002-0423-4731 } \\
\text { ORCID: 0000-0002-1370-7545 }\end{array}$ & \\
\hline How to Cite & \multicolumn{2}{|c|}{$\begin{array}{l}\text { Bayrak, G. and Küp, C. (2021). Yeşil Altyapı Uygulamaları Kapsamında Biyotutma } \\
\text { Sistemlerinin Yağmur Suyu Kirletici Giderim Verimlerinin Değerlendirilmesi, Kent } \\
\text { Akademisi, Volume, 14, Issue 3, Pages,.853-866. }\end{array}$} & $\begin{array}{l}\text { Kent Akademisi } \\
\text { Urban Academy }\end{array}$ \\
\hline
\end{tabular}

\title{
Yeşil Altyapı Uygulamaları Kapsamında Biyotutma Sistemlerinin Yağmur Suyu Kirletici Giderim Verimlerinin Değerlendirilmesi
}

Gökçen BAYRAK

Cansu KÜP ${ }^{2}$

\begin{abstract}
:
The effects of climate change are seen as excessive rainfall, erosion, floods, air pollution, water scarcity and drought in cities. Green infrastructure applications are used to reduce the effects of climate change in urban areas and to ensure environmental sustainability. With green infrastructure applications, by using bioretention systems as an ecological solution instead of structural solutions, both the treatment of stormwater from pollutants and the urban hydrological cycle are provided. Depending on the different land uses, various organic and inorganic substances carried by stormwater deteriorate the surface water quality. Bioretention systems reduce the amount of stormwater while at the same time reducing the pollutants in the water through physical, chemical and biological processes. In this study, the removal efficiencies of nitrogen, phosphorus and some heavy metals obtained in field studies were examined by considering the removal processes of various bioretention systems. It has been seen that removal efficiency varies depending on the pollutant type and concentration, types of land use, soil mixture prepared as a bioretention medium and the amount of precipitation. In this study, the removal efficiencies of nitrogen, phosphorus and some heavy metals obtained in field studies were examined by considering the removal processes of various bioretention systems. It has been seen that removal efficiency varies depending on the pollutant type and concentration, types of land use, soil mixture prepared as a bioretention medium and the amount of precipitation.
\end{abstract}

KEYWORDS: Bioretention, green infrastructure, pollutant removal efficiency, urban stormwater, diffuse pollution.

${ }^{1}$ Trakya Üniversitesi, Mimarlık Fakültesi, Peyzaj Mimarlığı Bölümü, Edirne, gokcenbayrak@trakya.edu.tr

${ }^{2}$ Trakya Üniversitesi, Fen Bilimleri Enstitüsü, Uygulamalı Bilimler ve Teknoloji Anabilim Dalı, Yüksek Lisans Öğrencisi, Edirne, cansukup3009@gmail.com

Evaluation of Stormwater Pollutant Removal Efficiency of Bioretention Systems within the Scope of Green Infrastructure Applications 


\section{ÖZ:}

İklim değişikliğinin etkileri kentlerde aşırı yağışlar, erozyon, seller, hava kirliliği, su kıtlığı, kuraklık olarak görülmektedir. İklim değişikliğinin kentsel alanlarda etkilerini azaltmak ve çevresel sürdürülebilirliğin sağlanması için yeşil altyapı uygulamaları karşımıza çıkmaktadır. Yeşil altyapı uygulamaları ile, yapısal çözümler yerine ekolojik çözüm olarak biyotutma sistemlerinin kullanılması ile hem yağmur suyunun kirleticilerden arıtılması hem de kentsel hidrolojik döngü sağlanmaktadır. Farklı alan kullanımlarına bağlı olarak yağmur suyuyla taşınan çeşitli organik ve inorganik maddeler yüzey suyu kalitesini bozmaktadır. Biyotutma sistemleri, akışa geçen yağmur suyu miktarını azaltırken aynı zamanda sudaki kirleticileri fiziksel, kimyasal ve biyolojik süreçlerle azaltmaktadır. Bu çalışmada, çeşitli biyotutma sistemlerinin giderim süreçleri göz önünde bulundurularak saha çalışmalarında elde edilen azot, fosfor ve bazı ağır metallerin giderim verimleri incelenmiştir. Giderim veriminin; kirletici tür ve konsantrasyonu, arazi kullanım çeşitleri, biyotutma ortamı olarak hazırlanan toprak karışımı ve yağış miktarına bağlı olarak değiştiği görülmüştür.

ANAHTAR KELIMELER: Biyotutma, yeşil altyapı, kirletici giderim verimi, kentsel yağmur suyu, yayılı kirlilik.

\section{GíRiş:}

Nüfusun hızlı bir şekilde artması ile özellikle kentsel alanlarda, çevre sorunları artmakta, habitatlar zarar görmekte ve arazi parçalanmaları ile ekolojik fonksiyonlar ve süreçlerde bozulmalar görülmektedir. Ayrıca, içme ve kullanma suyu ihtiyacı artarken, doğal su döngüsünü sağlayacak ortamlar geçirimsiz hale getirilmektedir. Su kaynaklarının artan nüfus ve kullanım kısıtlarını karşılayabilmesi için su kaynakları yönetimi gerekmektedir (Shakouri, 2016). Su kaynakları yönetimi, doğal döngüdeki suyun insanlar tarafından ekonomik, sosyal ve çevresel faydalar sağlayarak en verimli ve sistematik kullanımı anlamına gelmektedir (EEA, 2020). Su yönetimi ile suyun çok amaçlı kullanımının yanı sıra sürekli bir kaynak olması sağlanmaktadır. Doğal kaynaklardaki ve faaliyetler sonucu kirlenmiş suların yeniden kullanılabilmesi, yani sürdürülebilir olması için "bütünleşik su yönetimi” yapılması, su havzalarında bulunan her türlü arazi kullanımının belirlenerek "ortamlar arası izleme" yöntemiyle kontrol edilmesi gerekmektedir (Bayrak, 2011).

Kentsel yağmur suyu yönetimi, bütünleşik su yönetiminin önemli bir bileşenidir. Amaç, yağmur suyunun kentsel alanlara zarar vermeden uzaklaştırılmasını sağlamaktır (Demir, 2012). Kentlerde geleneksel yağmur suyu toplama sistemleri, yağmur sularını ayrık veya birleşik kanalizasyon sistemi ile hızlı bir şekilde ortamdan uzaklaştırmaktadır. $\mathrm{Bu}$ durum, özellikle yağmur sularının deşarj olduğu alıcı suların kirlenmesine ve yeraltı su kaynaklarının yeteri kadar beslenememesine neden olmaktadır (Bayrak ve ark., 2019).

Geleneksel yağmursuyu yönetiminin ekonomik ve ekolojik kısıtları nedeniyle, günümüzde yağmur suyu yönetimi için yeni yaklaşımlar geliştirilmiş̧ir. Bu yaklaşımlar sonucu gri ve yeşil altyapının bütünleştirilmesi, özellikle kentsel alanlarda yapılan planlamaların sürdürülebilirliğinin sağlanmasında önemli bir araç haline gelmiştir. Yeşil altyapı; çevre, toplumsal refah ve ekonomik sürdürülebilirlik için gerekli olan ekolojik bir çerçevedir. Ekosistem özellikleri bakımından değerli doğal alanları kapsayan, habitatları koruyan ve geliştiren, kentsel yaşama destek veren bütüncül bir sistemdir (Benedict ve McMahon, 2002; Gülgün ve Yazıc1, 2016). Yeşil altyapı temelli stratejik planlama yaklaşımları, bölgesel ve kentsel planlama süreçlerine entegre olan, doğal ve kültürel ekosistem değerlerini koruyup geliştiren ve planlama süreçlerinde yapısal çözümlemelerin tamamlayıcısı olan bütünleşik bir planlama aracıdır (Ely ve Pitman, 2014).

Son otuz yıldır yeşil altyapı terimi, yağmur suyu yönetim sistemlerinde ekolojik temelli tüm yaklaşımlar için kullanılmaktadır. Yeşil altyapı, doğal ve yarı doğal alanların, kırsal ve kentsel alanların ve yeşil alanların, ekosistem sağlığını ve esnekliğini geliştiren, biyoçeşitliliğin korunmasına katkıda bulunan ve insan topluluklarına fayda sağlayan karasal, tatlı su, kıyı ve deniz alanlarının ağıdır (Ely ve Pitman, 2014). Genel prensip, toprak ve bitki örtüsünü kullanarak yağmur suyunun geri dönüşümünü sağlamaktır. Yağmur suyunun toplanması ve yeniden kullanılması sağlanırken, ekolojik olarak hassas peyzajların korunması, yaban yaşam habitatlarının desteklenmesi, su kalitesinin iyileştirilmesi ve rekreasyonel faaliyetlere imkân sağlanması mümkün olmaktadır (Fisch, 2014). Kentler sürdürülebilirlik hedeflerine ulaşmaya çalışırken yeşil altyapıı, yatırım için hayati bir alan olarak görülmektedir. 
Sürdürülebilir yağmur suyu yönetimi için yeşil altyapılar şu uygulamaları içermektedir (Ely ve Pitman, 2014; Yang ve Lusk, 2018):

- Yağmur bahçeleri ve biyotutma alanları,

- Yeşil çatılar,

- Yeşil duvarlar,

- Yağmur suyu toplama ve yeniden kullanım sistemleri,

- Biyolojik yağmur hendekleri,

- Oluklarla toplanan yağmur suyunun atıksu kanalından ayrılması,

- Yağmur suyu göletleri,

- Kurakçıl peyzaj ve sulama,

- Geçirgen kaplama kullanmak (geçirgen asfalt, beton ve kaplama sistemleri).

Yeşil altyapı ağına katkıda bulunan öğeler ise (Ely ve Pitman, 2014):

- Kent parkları, açık alan rezervleri, mezarlıklar ve kamu parkları ve bahçeleri,

- Nehir ve dere koridorları, bisiklet yolları ve ana ulaşım yolları (karayolu, demiryolu ve tramvay) koridorları dahil olmak üzere yeşil yollar,

- Golf sahaları, okul ve diğer kurumsal oyun alanları ve diğer büyük parklar dahil olmak üzere spor ve eğlence tesisleri,

- Özel/yarı özel bahçeler, apartmanlar, arka bahçeler, balkonlar,

- Ulusal parklar ve doğa rezervleri, sulak alanlar ve kıyı kenarları dahil olmak üzere doğal yeşil alanlar,

- Taş ocakları, havaalanları ve büyük kurumsal ve üretim sahaları dahil olmak üzere kullanım alanları,

- Üzüm bağları, sebze bahçeleri, meyve bahçeleri ve çiftlikler dahil olmak üzere tarım arazileridir.

Yağmur bahçeleri ve biyotutma alanları, hemen hemen her geçirimli alana kurulabilen çok yönlü bahçelerdir. Biyotutma alanı olarak da bilinen bahçeler, çatılardan, kaldırımlardan ve sokaklardan akan suları toplayan ve infiltre eden bitki kaplı havzalardır. Bu uygulamada yağmur suyu, infiltrasyon, evapotranspirasyon gibi süreçlerle tutulur ve uzaklaştırılır. Yağmur bahçesi tasarımının esas fonksiyonu; yağmur suyunun infiltrasyonunu sağlayarak doğal ekosistem için su kalitesini yükseltmektir (Zhang ve ark., 2021).

Bu çalışmada, biyotutma alanları ve yağmur bahçelerinin saha uygulamalarında, yayılı kirletici kaynaklardan taşınan toplam azot $(\mathrm{TN})$, amonyum azotu $\left(\mathrm{NH}_{4}-\mathrm{N}\right)$, nitrat azotu $\left(\mathrm{NO}_{3}-\mathrm{N}\right)$, nitrit azotu $\left(\mathrm{NO}_{2}-\mathrm{N}\right)$, toplam fosfor $(\mathrm{TP})$ ve ağır metal $(\mathrm{Pb}, \mathrm{Zn}, \mathrm{Cu})$ giderim verimleri incelenmiştir.

\section{Yeşil Altyapı Teknikleri ile Kirletici Giderimi}

\subsection{Kentsel Yağmursuyu Kirleticileri}

Kentsel alanlardaki yollar, otoparklar ve yapılı alanlar gibi geçirimsiz yüzeylerden gelen ve yüzeysel akışa geçen yağmur suyu, birçok kirleticiyi de alıcı ortamlara taşımaktadır. Yayılı kirletici kaynaklardan yağmur suyu akışı ile taşınan kirlilik, yüzey suyu kalitesi üzerindeki önemli etkisiyle artan bir soruna neden olmaktadır. Yağmur suyu kirleticileri, bitki artıkları, kâğıt, plastik parçalarını içeren büyük kirleticiler ve besi maddeleri, ağır metaller ve hidrokarbonlar gibi çözünmüş kirleticiler olarak iki grupta incelenmektedir. Hayvansal atıklar ve atıksu toplama sistemlerinden bakteri ve virüsler; otomobil ve çatı kaplamalarından metaller, tarım alanları, bahçeler ve atmosferik birikimden besi maddeleri ve pestisitler; otomobillerden yağ ve gres, inşaat alanları ve yollardan sediman; endüstriyel alanlar ve otomobillerden toksik metaller ve tüm alanlardan organik maddeler ve katı maddeler kaynaklanmaktadır (Kloss ve ark., 2006; Zhang ve ark., 2021; Yang ve Lusk, 2018).

Yağmur suyunda bulunan en yaygın kirleticiler, toplam askıda katı maddeler (TSS), toplam azot (TN), toplam fosfor (TP)'dur (Zhang ve ark., 2021). Yağmur suyu akışında hem $\mathrm{N}$ hem de P, inorganik veya organik formların yanı sıra çözünmüş veya partikül formlarda da bulunur. Jeoloji, arazi kullanımı ve hidrolojik koşullara bağlı olarak yağmur suyu akışındaki besi maddelerinin organik inorganik formların nispi oranı değişmektedir. N'nin inorganik formları nitrat azotu $\left(\mathrm{NO}_{3}-\mathrm{N}\right)$, amonyum azotu $\left(\mathrm{NH}_{4}-\mathrm{N}\right)$ ve nitrit azotu $\left(\mathrm{NO}_{2}-\mathrm{N}\right)$ iken, organik formları çözünmüş organik $\mathrm{N}(\mathrm{DON})$ ve partikül organik N (PON)'dur. Yağmur suyu akışında, $\mathrm{P}$ ya çözünmüş formlar (örn., organik $\mathrm{P}$ ve ortofosfat, $\mathrm{PO}_{4-}$ P) halinde bulunmakta ya da ince partiküllerce (örn. P, kil ve organik madde) tutulmaktadır. Besi maddesi formlarındaki 
farklılıklar, mikrobiyal dönüşümleri ve iyonik formdaki besi maddelerinin tutulmasını etkileyebileceğinden, yağmur suyu akışındaki N ve P türlerinin belirlenmesi önemlidir (Yang ve Lusk, 2018).

Kentsel havzadan gelen yağmur suyu kalitesinin değerlendirilmesi genellikle "anlık ortalama konsantrasyon-event mean concentration (EMC)" değerleri kullanılarak yapılmaktadır. EMC değerleri, yağış ve saha özelliklerine bağlı olarak büyük ölçüde değişiklik göstermektedir. EMC, konsantrasyonun akış ağırlıklı ortalamasıdır ve litre başına miligram (mg/L) birimleri olarak ifade edilmektedir. Bir yă̆ış sırasında toplam kütlenin (M) toplam hacme (V) bölünmesi olarak tanımlanmaktadır. EMC daha sonra, tanımlanan yağış sırasında toplanan numunelerin "ortalama" veya "medyan" konsantrasyonunu temsil eden tek bir konsantrasyon olarak kabul edilmektedir (Bartley ve ark., 2012; Davis ve McCuen, 2005).

Örnekleme sırasında belirli akış koşulları hakkında bilgi olmadan konsantrasyon verilerinin toplanması, anlık ve toplam akış arasında niceliksel olarak ayrım yapmayı zorlaştırmaktadır. Literatür incelendiğinde, konsantrasyon verilerinin bazı çalışmalarda "aritmetik ortalama", bazı çalışmalarda ise "medyan" değerleri olarak verildiği görülmektedir. Verilerdeki değer farklılıklarının etkisini azaltmak için genellikle ortalama değerler yerine medyan kullanılması önerilmektedir (Bartley ve ark., 2012).

Yüzeysel akışs suyundaki ağır metal konsantrasyonları Tablo 1'de, azot ve fosfor formlarına ait değerler ise Tablo 2'de gösterilmektedir.

Tablo 1. Yağmur suyundaki ağır metal konsantrasyonları (Zhang ve ark., 2021; Bannerman ve ark., 1993)

\begin{tabular}{|c|c|c|c|c|c|}
\hline Kirletici (mg/L) & Çim alanlar & Çatılar & Sokaklar & Araç yolları & Caddeler \\
\hline T Pb & - & 21 & 33 & 17 & 55 \\
\hline T Zn & 59 & 149 & 220 & 107 & 339 \\
\hline T Cu & 13 & 15 & 24 & 17 & 56 \\
\hline T Cd & - & - & 0,8 & 0,5 & 1,4 \\
\hline T Cr & - & - & 5 & 2 & 12 \\
\hline
\end{tabular}

Tablo 2. Yağmur suyundaki kirletici konsantrasyonları

\begin{tabular}{|c|c|c|c|}
\hline Kirletici (mg/L) & Yerleşim Alanı & Ticari Alan & Kaynak \\
\hline \multirow{4}{*}{$\mathrm{NO}_{3}-\mathrm{N}$} & 0,9 & 0,93 & (Chow ve ark., 2013) \\
\hline & 2,4 & 2,8 & (Nazahiyah, 2005) \\
\hline & 0,736 & 0,572 & (Van der Tak \& Edwards, 2001) \\
\hline & 0,23 & 0,26 & (Van der Tak \& Edwards, 2001) \\
\hline \multirow{2}{*}{$\mathrm{NO}_{2}-\mathrm{N}$} & 0,011 & 0,006 & (Chow ve ark., 2013) \\
\hline & 0,10 & 0,43 & (Nazahiyah, 2005) \\
\hline \multirow{2}{*}{$\mathrm{NH}_{4}-\mathrm{N}$} & 0,19 & 0,71 & (Chow ve ark., 2013) \\
\hline & 3,50 & 3,80 & (Nazahiyah, 2005) \\
\hline \multirow{2}{*}{ TN } & 2,53 & 1,82 & (Van der Tak \& Edwards, 2001) \\
\hline & $0,50-18,30$ & & (Göbel ve ark., 2007) \\
\hline \multirow{9}{*}{$\mathbf{T P}$} & 0,38 & 0,69 & (Chow ve ark., 2013) \\
\hline & 0,35 & & (Francey ve ark., 2010) \\
\hline & 0,53 & & (McLeod ve ark., 2006) \\
\hline & & 0,15 & (Francey ve ark., 2010) \\
\hline & & 0,45 & (McLeod ve ark., 2006) \\
\hline & $0,23-0,34$ & & (Göbel ve ark., 2007) \\
\hline & 0,383 & 0,201 & (Van der Tak \& Edwards, 2001) \\
\hline & 0,57 & 0,32 & (Van der Tak \& Edwards, 2001) \\
\hline & 263 & 201 & (Stephan \& Endreny, 2016) \\
\hline
\end{tabular}




\subsection{Kirletici Giderim Süreçleri}

Biyotutma sistemleri ve yağmur bahçeleri, yüzeysel akışla kirleticileri taşıyan yağmur suyunu infiltre ederken aynı zamanda filtrelemekte, adsorbe etmekte, bitki kökleriyle tutmaktadır. Şekil 1'de biyotutma sistemi bileşenleri gösterilmektedir.

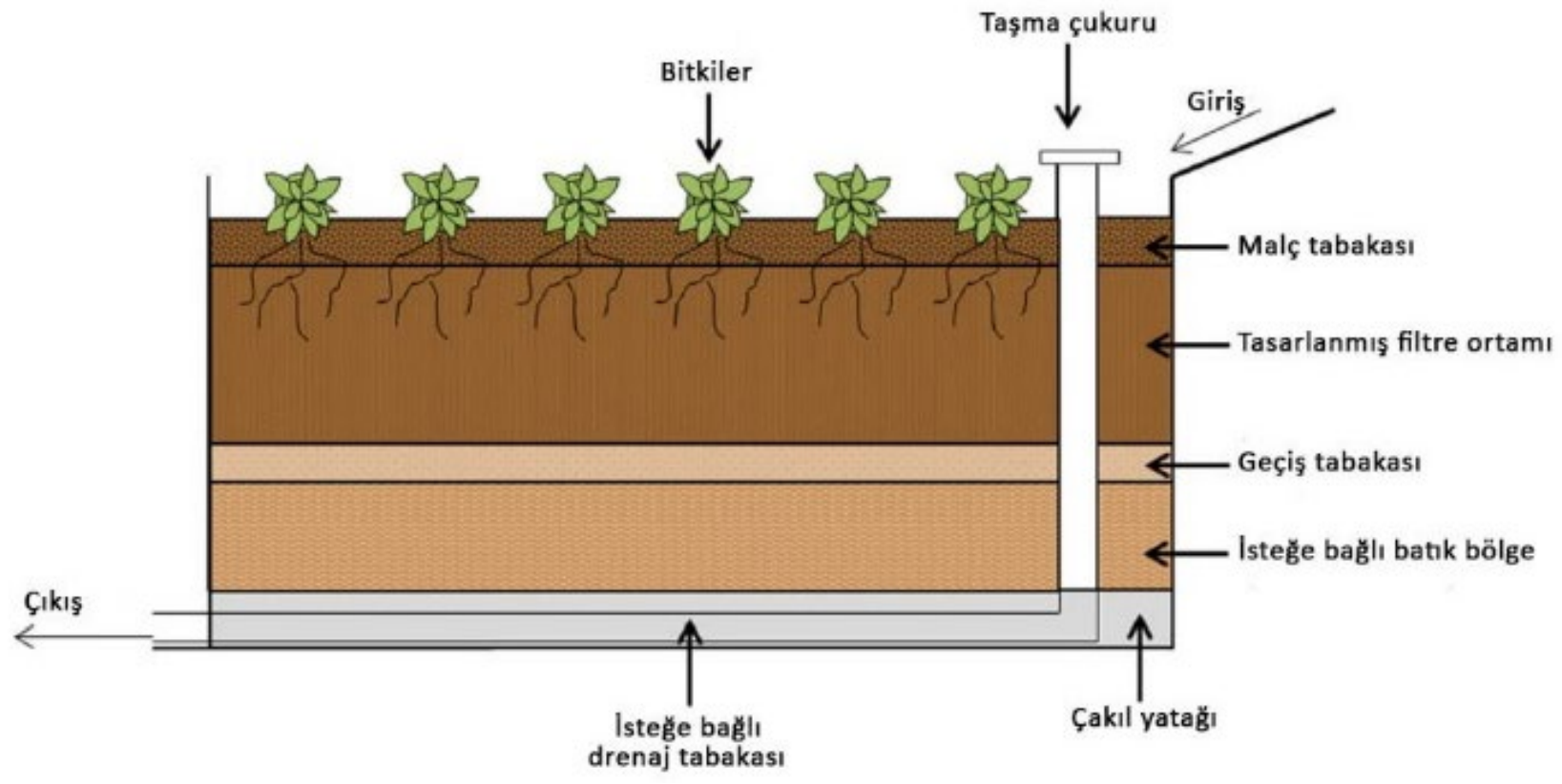

Şekil 1. Biyotutma sistemi bileşenleri (Goh ve ark., 2019)

Biyotutma, kullanılan toprak karışımı ve bitkiler ile kirletici arasında gerçekleşen bir süreçler bütünüdür. Bunlar (PGCM, 2007; Chow ve ark., 2013):

Tutma: Yağmur suyuyla gelen akışın bitkiler ve toprak tarafından tutulmasıdır.

Sedimantasyon: Partiküler maddenin sudan uzaklaştırılması için birincil mekanizmadır. Akıntının yavaşlamasıyla askıda katı maddelerin çökelmesidir. Bu işlem, biyotutma tesisinin yüzeyinde meydana gelmekte ve filtre ortamına girmeden önce ön işlem sağlamaktadır. Yüksek yoğunluklu partiküller, sedimantasyon yoluyla etkin bir şekilde uzaklaştırılmaktadır.

Evaporasyon: Suyun buharlaşmasıdır.

Transpirasyon: Yapraklarda gerçekleşen terleme olayıdır. Bir bitkinin kökleriyle alınan suyun \%90'ından fazlası su buharı olarak havaya geri dönmektedir.

Evapotranspirasyon: Bitkinin su tüketimi (terleme) ve buharlaşma ile birlikte su toplamıdır. Biyotutma tesisi tasarımı, bu işlemin gerçekleşme potansiyelini en üst düzeye çıkarmaktadır.

İnfiltrasyon: Suyun toprağın boşluklarından aşağı doğru geçişidir.

Termal Azalma: Akış suyu sıcaklığının toprakta azalmasıdır.

Filtrasyon: Partiküllerin malç ve topraktan geçerken akıştan filtrelenmesi olayıdır. Biyotutma tesislerinde, filtrasyon çoğu partikülü akıştan uzaklaştırmaktadır. Sahada uygulanan biyotutma sistemlerinde askıda katıların mükemmel şekilde uzaklaştırıldığ kaydedilmiştir. 
Adsorpsiyon: Kil ya da humusun dış yüzeyindeki negatif yük nedeniyle sıvı, gaz veya çözünmüş bir maddeyi tutmasıdır. Malç ve bitki maddesinin parçalanmasıyla biyotutma tesislerinde bulunabilen humus, metalleri, nitratları ve ortofosfatları adsorbe etmektedir.

Absorpsiyon: Suyun bitki kök kılları ve mantarlar tarafından alınmasıdır.

Volatilizasyon: Bir maddenin daha uçucu buhar formuna dönüştürülmesidir.

Asimilasyon: Canlıların dış ortamdan aldıkları inorganik maddelerden organik maddeleri üretmeleridir. Bitki kökleri doğrudan çözünmüş inorganik azotu asimile etmekte ve mikroorganizmaların zenginleşmesine katkıda bulunmaktadır. Belirli türdeki kirleticiler için biyotutma tesislerinde uygun bitkiler seçilmelidir. Metal tutulumunun ve birikiminin olduğu bitkilerin hasat edilmesi, kirleticinin yeniden ortama ulaşmasını engellemektedir.

Degradasyon: Organik bileşiklerin toprak ortamındaki mikroorganizmalar tarafından ayrıştırılmasıdır. Fizikokimyasal süreçlere kıyasla genellikle yavaştır. Degradasyonun gerçekleşebilmesi için uygun nem ve sıcaklık koşullarının sağlanması gerekmektedir.

Nitrifikasyon: Amonyak ve amonyum iyonlarınının bakteriler tarafından önce nitrite $\left(\mathrm{NO}_{2}\right)$ sonra da nitrata $\left(\mathrm{NO}_{3}\right)$ oksidasyonudur. Bu işlem iki grup ototrofik bakteri tarafından gerçekleştirilir. NH3'ten 'ye kadar olan ilk adım, NH3 oksitleyiciler tarafından katalize edilir ve 'den 'ye kadar olan ikinci adım, oksitleyiciler tarafından gerçekleştirilir. İlk grubun en iyi çalışılmış üyesi Nitrosomonas europaea'dır ve Nitrobacter winogradskyi oksitleyicilerin bir temsilcisidir (Wrage ve ark., 2001).

Denitrifikasyon: Nitratın kademeli olarak mikrobiyal indirgenmesidir. Reaksiyonlar, Pseudomonas, Bacillus, Thiobacillus, Propionibacterium dahil olmak üzere bakteri taksonlarında yaygın olarak bulunan denitrifiye ediciler tarafindan gerçekleştirilir. Sonuçta ya $\mathrm{N}_{2}$ ya da $\mathrm{N}_{2} \mathrm{O}$ gaz halinde açığa çıkar. Denitrifikasyon, suya doygun, anaerobik ortamlarda gerçekleşmektedir (Wrage ve ark., 2001).

\subsection{Kirletici Giderim Verimleri}

Yağmur suyu yönetimi için yaygın olarak bir dizi arıtma tekniği kullanılmaktadır. Matematiksel olarak kirletici tutma verimi, bir arıtma ortamı tarafından tutulan kirletici miktarının girişteki miktara oranıdır. Çıkıştaki kirletici miktarını ölçmek, tutulan miktarı ölçmekten daha kolay olduğundan, kütle dengesi ilkeleri kullanılarak tutma verimi TE, şu şekilde verilir:

$$
T E=1-C \text { çıkış/Cgiriş }
$$

TE, giderim verimi; Cçıkış, biyotutma alanından çıkan yağmur suyundaki kirletici konsantrasyonu; Cgiriş, biyotutma alanına gelen çıkan yağmur suyundaki kirletici konsantrasyonudur (Davis ve McCuen,2005).

Kirletici giderim verimlerinin değerlendirilmesinde, sadece yüzdeye veya kısmi giderime odaklanmak, zamanla değişen bir süreci yeterli şekilde açıklamamaktadır. Yağış olaylarının dinamik doğası nedeniyle, kararlı bir durumdan söz edilememektedir. Bir kirletici giderimi uygulaması için hem yüzeysel akışla gelen yağmur suyu miktarının hem de kirletici konsantrasyonlarının girdi ve çıktı oranları bir olayın zamanına göre ve her olayda değişmektedir. Bu nedenle, giderimler de EMC'de bir değişiklik olarak sunulmalı ve tartışılmalıdır (Davis ve McCuen,2005).

Kimyasal ve biyolojik süreçler sonucu bir kirletici formu başka bir forma dönüşebilmekte, bu da giderime ya da negatif giderime neden olmaktadır. Biyotutma alanlarında yüzey akışından kirletici madde uzaklaştırılması, kirletici maddelerin ortamda birikmesine, sonraki yağış olayı sırasında bu kirleticilerin yıkanması ile çıkış değerlerinin giriş konsantrasyonlarından daha yüksek olmasına neden olmaktadır. Bu olay "negatif giderim" olarak adlandırılmaktadır. Bu durum azot bileşiklerinde yaygın olarak görülmektedir (Ahiablame ve ark., 2012).

Biyotutma sistemlerinde kirletici giderim verimlerinin belirlenmesi amacıyla birçok saha ve laboratuvar çalısması yapıldığı görülmektedir. Tablo 3'te bazı ağır metal giderim verimleri, Tablo 4'te sahada uygulanan biyotutma sistemlerinde $\mathrm{N}$ ve $\mathrm{P}$ giderim verimleri gösterilmektedir. 
Tablo 3. Sahada uygulanan biyotutma sistemlerinde ağır metal giderim verimleri (\%)

\begin{tabular}{|c|c|c|c|}
\hline $\mathrm{Pb}$ & $\mathrm{Zn}$ & $\mathrm{Cu}$ & Kaynak \\
\hline $31-98$ & $62-99$ & $43-99$ & (Ahiablame ve ark., 2012) \\
\hline $74-99$ & $73-99$ & $20-99$ & (Ahiablame ve ark., 2012) \\
\hline 75 & $68-93$ & & (Davis ve ark., 2009) \\
\hline & $54-99$ & & (Davis ve ark., 2003) \\
\hline $70-95$ & $64-95$ & $-43-97$ & (Dietz, 2007) \\
\hline $70-100$ & $64-100$ & $43-99$ & (Hunt ve ark., 2006) \\
\hline$>90$ & $>90$ & $>90$ & (Raspati ve ark., 2017) \\
\hline 81 & 98 & 99 & (LeFevre ve ark., 2015) \\
\hline 76,10 & 71,30 & & (Liu ve ark., 2014) \\
\hline $31-100$ & $50-99$ & $-9-99$ & (Rocnamara ve Derry, 2017) \\
\hline $32-100$ & $60-99$ & $65-98$ & \\
\hline 91,80 & 85,10 & 97 & \\
\hline$>95$ & 99 & & \\
\hline
\end{tabular}

Tablo 4. Sahada uygulanan biyotutma sistemlerinde azot ve fosfor giderim verimleri (\%)

\begin{tabular}{|c|c|c|c|}
\hline NOx-N & $\mathrm{NH}_{4}-\mathrm{N}$ & TN & TP \\
\hline \multirow[t]{2}{*}{$1-83$} & $-65-82$ & $32-99$ & \\
\hline & & $14-61$ & $-3-99$ \\
\hline-209 & 82 & 21 & \\
\hline \multirow[t]{2}{*}{-477} & 74 & 75 & \\
\hline & & $19,9-90,8$ & $-2-19$ \\
\hline \multirow[t]{4}{*}{43} & 72 & 20 & \\
\hline & & $90-95$ & 31,4 \\
\hline & & $49-59$ & $77-79$ \\
\hline & & $30-99$ & $24-99$ \\
\hline $15-16$ & & $4-99$ & \\
\hline 87 & 79 & 79 & $-240-99$ \\
\hline $13-75$ & $-1-86$ & $40-59$ & $10-78$ \\
\hline 24 & 87 & & $70-85$ \\
\hline \multirow[t]{4}{*}{67} & 82 & 51 & \\
\hline & & 58,6 & 86 \\
\hline & & 37 & $36,42-75,33$ \\
\hline & & 40 & $65-87$ \\
\hline \multirow[t]{2}{*}{$13-75$} & $-1-86$ & 40 & -108 \\
\hline & & 32,2 & $76,9-97,2$ \\
\hline 4,9 & 70,6 & 32,1 & \\
\hline \multirow[t]{2}{*}{$-3,3$} & $-1,9$ & 72,5 & \\
\hline & & $39,8-76,67$ & $65-87$ \\
\hline \multirow[t]{2}{*}{42,3} & 64,6 & 50,7 & \\
\hline & & 29,5 & 46 \\
\hline \multirow[t]{2}{*}{$\begin{array}{l}-766-96 \\
\end{array}$} & $-136-96$ & & $-240-87$ \\
\hline & & 56 & 55,1 \\
\hline \multirow[t]{5}{*}{-120} & & 4,3 & \\
\hline & & 41 & \\
\hline & & $-3-99$ & \\
\hline & & 89,00 & 61,10 \\
\hline & & $38,70-47,93$ & $-65-240$ \\
\hline 33 & 70 & 54 & \\
\hline 8 & 84 & 54 & \\
\hline 78,5 & 82,4 & 72,5 & \\
\hline $16-27$ & & 49 & $-240-65$ \\
\hline 32,1 & 82,9 & 68,1 & \\
\hline-97 & - & 33 & \\
\hline \multirow[t]{2}{*}{19} & 47 & 34 & \\
\hline & & 25 & 74,1 \\
\hline 3,2 & 10 & 25 & \\
\hline 16,7 & 86 & 34 & \\
\hline
\end{tabular}

(Ahiablame ve ark., 2012)

(Ahiablame ve ark., 2012)

(Brown ve Hunt III, 2011)

(Brown ve Hunt III, 2011)

(Carpenter ve Hallam, 2010)

(Chen ve ark., 2013) (Davis, 2007)

(Davis ve ark., 2006)

(Davis ve ark., 2009)

(Davis ve ark., 2003)

(De Rozarj ve ark., 2018) (Dietz, 2007) (Dietz, 2007)

(Dietz ve ark.,2006)

(Geronimo ve ark., 2013)

(Hatt ve ark., 2009)

(Hunt ve ark., 2006)

(Hunt ve ark., 2006)

(Hunt ve ark., 2008)

(Hunt ve ark., 2008)

(Jiang ve ark., 2017)

(Jiang ve ark., 2017)

(Jiang ve ark., 2018)

(LeFevre ve ark., 2015)

(LeFevre ve ark., 2015) (Li ve Davis, 2014)

(Li ve Davis, 2014)

(Liu ve Davis, 2014) (Liu ve ark., 2014)

(Macnamara ve Derry, 2017)

(Mangangka ve ark., 2015)

(Passeport ve ark., 2009) (Peterson, 2016) (Peterson, 2016)

(Roseen ve ark., 2006)

(Roseen ve ark., 2006)

(Singh ve ark., 2019)

(Wan ve ark., 2018)

(Wang ve ark., 2017)

(Wang ve ark., 2017)

(Zhou ve ark., 2017)

Evaluation of Stormwater Pollutant Removal Efficiency of Bioretention Systems within the Scope of Green Infrastructure Applications 


\subsection{Kirletici Giderimini Etkileyen Etmenler}

Kirletici maddelerin etkili bir şekilde giderildiği ve akış hacminin azaltıldığı biyotutma sisteminin performansı, farklı bölgelerin farklı akış özelliklerine, yağış rejimlerine, nüfus yoğunluğuna ve arazi kullanımına bağlı olarak değişiklik göstermektedir (Goh ve ark., 2019).

Biyotutma alanları ve yağmur bahçelerinde, yağmur suyunu tutma, kirleticiyi giderme ve bitki yetiştirme ortamı olarak hazırlanan ve yeterli geçirgenliği olan toprak karışımı, biyotutmanın çok önemli bir parçasıdır. Toprağın hidrolik iletkenliği, gözeneklerin boyutuna bağlı olup geçirgenliğin arttırılması için 75-120 cm derinliğinde kumlu karışım önerilmektedir (Zhang ve ark., 2021; Goh ve ark., 2019).

Biyotutma alanlarının tasarımında bitki türlerinin seçimi için ana kriterler, yerel peyzaj ve ekoloji için uygunluk, aşırı koşullar altında hayatta kalma yeteneği ve hızlı ancak istilacı olmayan gelişimdir. Kirleticileri tür ve miktarına uygun bitki ve türler seçilmelidir (Goh ve ark., 2019).

Yeşil altyapı uygulamaları yapan birçok ülkede (Amerika Birleşik Devletleri, Kanada, Malezya), biyotutma sistemlerinde standardizasyon için kılavuzlar hazırlanmıştır. Kılavuzlarda, farklı konumdaki alanların toprak ve iklim özelliklerine göre değişen farklı toprak kompozisyonları önerilmektedir. Kum, yüksek oranda hidrolik iletkenlik sağlar, üst topraktaki yumuşak kil, özellikle ağır metaller olmak üzere yüksek düzeyde kirleticiyi adsorbe eder ve organik maddeler (kompost) mikrobiyal gelişim ve bitki örtüsü için gereklidir. Çeşitli kılavuzlarda, biyotutma alanlarının genellikle TSS için \%75-97, TN için \%30-66 ve TP için \%35-85 giderim verimi sağlanacak şekilde tasarlanması önerilmektedir (Goh ve ark., 2019).

Kirletici gideriminde ortamın giderim kapasitesi, adsorpsiyonun gücüne ve gelen kirleticilerin konsantrasyonuna bağlıdır. Metaller ve hidrokarbonlar için ortamın giderim kapasitesi uzun yıllar devam ederken fosfor için birkaç yıl veya daha kısa bir zaman diliminde tükenmektedir (Chow ve ark., 2013).

Biyotutma sistemindeki azot giderimi, organik, inorganik, partikül ve çözünmüş azot dahil olmak üzere çeşitli azot formlarının farklı kimyasal özellikleri ve azot dönüşümü için mevcut biyotutma sisteminin sınırlamaları nedeniyle değişkendir. Biyotutma sistemini tasarlamadan önce yağmur suyu akışındaki azot kirleticilerinin bileşiminin ve oranının belirlenmesi gerekmektedir (Zhang ve ark., 2021; Li ve Davis, 2014). Biyotutma için toprak karışımı kritiktir, temel olarak, iyi geçirgenliği ve stabil bir çalışma koşulunu korumak için yarıdan fazla kum içermelidir. Diğer dolgu malzemeleri azot giderimi üzerinde farklı etkilere sahiptir. Örneğin, talaş, gazete ve biyokömür azot giderimini arttırmakta, yalnızca kum ve toprak karışımı zayıf bir performans göstermektedir. Kirletici giderme verimi, farklı iklim koşulları, kirletici yükleri ve toprak özelliklerine bağlı olmakla birlikte yüzeyde bitkilerin kullanılması azot giderimini arttırmaktadır. Aerobik koşullar altında biyotutma üst katmanında organik ve inorganik azotun bazı dönüşüm ve uzaklaştırma süreçleri bulunmaktadır.

Biyotutma sistemindeki azot giderimi ve dönüşümünün ana süreçleri şunları içermektedir (Zhang ve ark., 2021):

1. PON sedimantasyonu/filtrasyonu,

2. Organik azotun mineralizasyonu,

3. $\quad \mathrm{NH}_{4}{ }^{+}$-N fiksasyonu (iyon değişimi),

4. Mikrobiyal azot alım1,

5. Mikrobiyal azot dönüşümü (yani nitrifikasyon ve denitrifikasyon).

Şekil 2'de biyotutma sistemlerinde azot giderim süreçleri gösterilmektedir. 


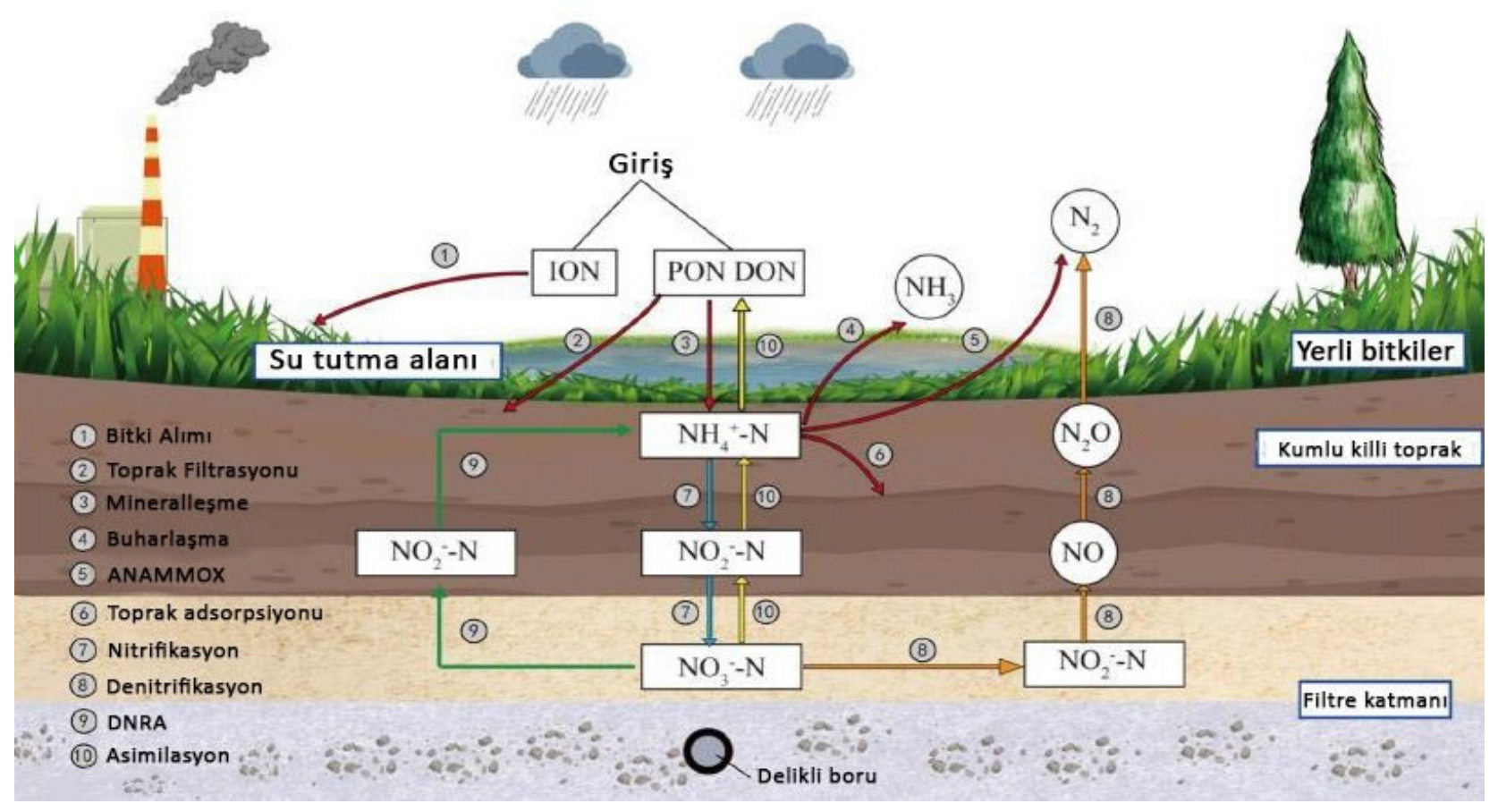

Şekil 2. Biyotutma sistemlerinde azot giderim süreçleri (Zhang ve ark., 2021)

PON, toprak filtrasyonu ile uzaklaştırılmakta ve yağmur suyu akışındaki DON, mikrobiyal mineralizasyon yoluyla

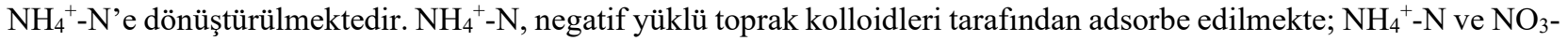
$\mathrm{N}$ bitkiler tarafindan absorblanmakta ve asimile edilmektedir. Asimilasyon, $\mathrm{NH}_{4}{ }^{+}-\mathrm{N}$ ve $\mathrm{NO}_{3}-\mathrm{N}$ 'nun mikrobiyal hücre kütlesine veya bitki biyokütlesine dönüştürüldüğü, burada geçici olarak PON, toprak filtrasyonu ile uzaklaştırılmakta ve yağmur suyu akışındaki DON, mikrobiyal mineralizasyon yoluyla $\mathrm{NH}_{4}{ }^{+}-\mathrm{N}$ 'e dönüştürülmektedir. $\mathrm{NH}_{4}{ }^{+}-\mathrm{N}$, negatif yüklü toprak kolloidleri tarafindan adsorbe edilmekte; $\mathrm{NH}_{4}{ }^{+}-\mathrm{N}$ ve $\mathrm{NO}_{3}-\mathrm{N}$ bitkiler tarafindan absorblanmakta ve asimile edilmektedir. Asimilasyon, $\mathrm{NH}_{4}{ }^{+}-\mathrm{N}$ ve $\mathrm{NO}_{3}$-N'nun mikrobiyal hücre kütlesine veya bitki biyokütlesine dönüştürüldügü, burada geçici olarak organik azot olarak depolandığ nitrifikasyon ile uzaklaştırılmaktadır. Bunun için $\mathrm{NH}_{4}{ }^{+}-\mathrm{N}$, aerobik koşullar altında önce $\mathrm{NO}_{2}-\mathrm{N}^{\prime}$ a ve ardından $\mathrm{NO}_{3}-\mathrm{N}^{\prime} \mathrm{a}$ dönüştürülmektedir. Mikroorganizmalar tarafından asimilasyon veya adsorpsiyon yoluyla azot tutulumu, kalıcı uzaklaştırmadan ziyade geçici azot uzaklaştırılmasına neden olmakta ve koşulların değişmesiyle azotun geri salımı gerçekleşmektedir. $\mathrm{NH}_{4}{ }^{+}$-N'ndan farklı olarak $\mathrm{NO}_{\mathrm{x}}-\mathrm{N}$ negatif yüklü olup toprak parçacıkları tarafından adsorbe edilmemekte, biyotutma sisteminde hareketli hale gelmektedir. Nitrat, biyotutma sisteminde denitrifikasyon yoluyla $\mathrm{N}_{2}$ formunda kalıcı olarak uzaklaştırılmaktadır. Denitrifikasyon anoksik veya anaerobik koşullar altında oluşmakta, organik karbon kaynağı, kükürt veya demir gibi substratlar gerektirmektedir (Zhang ve ark., 2021).

Li ve Davis (2014), 16 yağış olayı sırasında konvansiyonel biyotutma alanında TN, PON, $\mathrm{NO}_{3}-\mathrm{N}, \mathrm{NO}_{2}-\mathrm{N}, \mathrm{NH}_{3}-\mathrm{N}$ ve DON analiz etmişlerdir. PON'un sedimantasyon/filtrasyon, $\mathrm{NH}_{3}-\mathrm{N}$ 'nin iyon değişimi/sorbsiyon ve $\mathrm{NO}_{2}-\mathrm{N}^{\prime}$ nin oksidasyon yoluyla etkin bir şekilde uzaklaştırıldığını, ancak, biyotutma hücresinden önemli miktarda $\mathrm{DON}$ ve $\mathrm{NO}_{3}$ N'nin filtrasyonu ile TN konsantrasyonda sadece \%9 azalma sağlandığını belirtmişlerdir. Biyotutma hücresinde tutulan PON ve bitki artıkları, DON olarak süzülmekte veya $\mathrm{NO}_{3}-\mathrm{N}^{\prime} y e$ mineralize edilmektedir. Azotun çıkış formlarına $\mathrm{NO}_{3}-$ $\mathrm{N}(\% 46)$ ve DON (\%42) hakimdir. Bu nedenle biyotutma sistemlerinde etkili azot giderimi için, $\mathrm{NO}_{3}-\mathrm{N}$ için denitrifikasyon koşullarının yaratılmasına ek olarak, DON sızıntısının önlenmesi gerekmektedir (Li ve Davis, 2014).

İklimsel koşullar, biyotutma sistemindeki azot giderme verimini etkilemekte; bu etki, biyotutma sistemindeki mikrobiyal büyüme ve nitrifikasyon/denitrifikasyon süreçleri üzerinde önemli bir etkiye sahip olan sicaklık değişimi ile gerçekleşmektedir. Uygun bir aralıkta sıcaklık artışı ile denitrifikasyon verimi, bitki büyümesi ve bitkiler tarafından besin alımı artmaktadır. Kurak dönemlerden sonra gerçekleşen yağışlı dönemlerde, toprakta azot ve fosfor içeren besi maddeleri yeniden ortama salınmaktadır. Kuru ve havalandırılmış topraklarda organik azotun mineralleşme oranını ve inorganik azot içeriği artmaktadır. Ayrıca, havada kurutmanın neden olduğu kuruma ile mikrobiyal ölüm 
gerçekleşmekte ve azot içeren kimyasallar salınmaktadır. Biyotutma sistemi kuruma sürecine girdikçe denitrifikasyon verimi düşmekte ve yüksek çözünürlüğe ve hareketliliğe sahip nitrat birikimi gerçekleşmektedir (Zhang ve ark., 2021). Ayrıca, biyotutma sistemine giren azot konsantrasyonu da azot giderme verimliliği üzerinde etkilidir. Düşük giriş konsantrasyonu ile giderim veriminin yüksek giriş konsantrasyona göre daha yüksek olduğu gösterilmiştir (Goh ve ark., 2019).

Ortam reaksiyonu incelendiğinde; $\mathrm{pH}$ 7,5-8 aralığında optimum giderim gerçekleştiği, $\mathrm{pH}$ 6,5 ve altındaysa sürecin inhibe olduğu ve $\mathrm{pH}$ yükseldikçe nitrit gideriminin arttı̆̆ belirtilmektedir. Hidrolik kalma süresi (HRT), azot biyotransformasyonunu etkilemektedir (Zhang ve ark., 2021).

TP'nin uzaklaştırılması, filtreleme, adsorpsiyon ve mikrobiyal aktivite süreçleriyle gerçekleşmektedir. TP giderimini etkileyen faktörler arasında bitkilerin varlığı, filtre ortamı karışım oranları ve toprak iletkenliği yer almaktadır. TP giderimi, bitki kullanılan biyotutma ortamlarında bitkisiz ortamlara göre daha yüksektir ve düşük sıcaklıkta yüksek oranda gerçekleşmektedir. Tanecik boyutu büyüdükçe tutulumun azalmakta, ayrıca, fosfor içeriği yüksek toprakların kullanıldığı biyotutma sistemlerinde çıkış suyunda TP artışı gerçekleşmektedir (Goh ve ark., 2019).

Kluge vd. (2018), uzun süreli biyotutma sistemlerinde (11-22 yıl) metal birikimini incelemişlerdir. Toprağın üst tabakasında $(0-20 \mathrm{~cm})$ önemli miktarda metal birikimi görülmüştür, tüm metallerin ortalama konsantrasyonları toprak yüzeyinde $(0-10 \mathrm{~cm})$ en yüksek değerlere ulaşırken, artan derinlikte metal konsantrasyonlarının azaldığı gözlenmiştir. Akan suyun giriş noktalarında yüksek metal konsantrasyonları bulunmuştur. Giriş noktasından 1,5 m' den daha fazla bir mesafede, metal konsantrasyonları, başlangıçtaki toprak konsantrasyonlarına kıyasla az miktarda artmıştır. Sızdırmazlık testleri ile biyotutma toprak ortamında biriken metallerin çoğunun suda az çözünür olduğunu belirlemişlerdir (Kluge ve ark., 2018).

\section{SONUÇ:}

$\mathrm{Bu}$ çalışmada, biyotutma alanları ve yağmur bahçelerinin saha uygulamalarında, yayılı kirletici kaynaklardan taşınan $\mathrm{TN}, \mathrm{NH}_{4}-\mathrm{N}, \mathrm{NO}_{3}-\mathrm{N}, \mathrm{NO}_{2}-\mathrm{N}, \mathrm{TP}$ ve $\mathrm{Pb}, \mathrm{Zn}$ ve $\mathrm{Cu}$ giderim verimlerinin değerlendirilmesi için öncelikle yağmursuyu kirleticileri, biyotutma alanlarının bileşenleri ve biyotutma süreçleri incelenmiştir.

Değerlendirme sonucunda; yağmur suyunda bulunan en yaygın kirleticilerin, TSS, TN, TP ve ağır metaller olduğu, yağmur suyu akışında hem $\mathrm{N}$ hem de P'nin inorganik veya organik formlarının yanı sıra çözünmüş veya partikül formlarda bulunduğu belirlenmiş̧ir.

Tablo 3 ve Tablo 4 incelendiğinde, biyotutma sistemlerinin yağmur suyu akışındaki kirletici maddeleri değişken oranlarda $\left(\mathrm{NO}_{\mathrm{x}}-\mathrm{N} \%\right.$-477 ile 96, $\mathrm{NH}_{4}-\mathrm{N} \%$-136 ile 96, TN \%-3 ile 99, TP \%-240 ile 99, $\mathrm{Pb} \% 31-100, \mathrm{Zn} \% 50-99, \mathrm{Cu}$ \%20-99) azalttığı görülmektedir. Söz konusu kirleticilerin bazı uygulamalarda neredeyse tamamı giderilirken, negatif giderim oranları da dikkat çekicidir.

Yapılan çalışmalar incelendiğinde biyotutma sisteminin performansının;

- Yağış rejimlerine,

- Nüfus yoğunluğuna,

- Arazi kullanımına,

- Yeterli geçirgenliği olan toprak karışımına,

- Biyotutma alanlarında kullanılan bitki türlerine,

- Kirletici giriş konsantrasyonuna,

Azot giderimi için;

- Yağmur suyundaki azot formları ve oranlarına,

- Biyotutma alanlarında kullanılan karbon kaynaklarının (pamuk, gazete kâğıdı vb.) varlığına,

- Denitrifikasyon sürecini etkileyen faktörlerin iyileştirilmesine,

- Sicaklık değişimine,

- Ortam reaksiyonuna,

- Hidrolik kalma süresine, 
Fosfor giderimi için;

- Tanecik boyutuna,

- Sicaklığa,

- Toprak karışımına,

Bağlı olduğu ortaya konmaktadır. Ayrıca, kirletici giderim verimlerinin değerlendirilmesinde, sadece giderim oranının dikkate alınmasının zamanla değişen bir süreci yeterli şekilde açıklamayacağı, yağış olaylarının dinamik doğası nedeniyle, kararlı bir durumdan söz edilemeyeceği, giderim miktarlarının EMC'de bir değişiklik olarak sunulması gerektiği vurgulanmaktadır.

Sonuç olarak, kentsel alanlarda yüzeysel akışla taşınan kirleticilerin, yapısal çözümler yerine ekolojik olarak giderildiği biyotutma sistemlerinin, alıcı su kaynaklarının su kalitesinde bozulmaları azaltacak, kanalizasyon sistemi ve arıtma tesisi su ve kirletici yükünü azaltacak, çevresel faydası yüksek olan uygulamalar olduğu düşünülmektedir.

\section{Etik Standart ile Uyumluluk}

Çıkar Çatışması: Yazarlar herhangi bir çıkar çatışmasının olmadığını beyan eder.

Etik Kurul İzni: Bu çalışma için etik kurul iznine gerek yoktur.

Finansal Destek: Bu çalışma, Trakya Üniversitesi Bilimsel Araştırma Projeleri Birimi (TÜBAP, Proje Numarası: 2020/76) tarafından desteklenen yüksek lisans tezinin bir bölümünü oluşturmaktadır.

\section{KAYNAKÇA:}

Ahiablame, L. M., Engel, B. A., Chaubey, I. (2012). Effectiveness of low impact development practices: literature review and suggestions for future research. Water, Air, \& Soil Pollution, 223(7), 4253-4273.

Bannerman, R. T., Owens, D. W., Dodds, R. B., Hornewer, N. J. (1993). Sources of pollutants in Wisconsin stormwater. Water Science and technology, 28(3-5), 241-259.

Bartley, R., Speirs, W. J., Ellis, T. W., Waters, D. K. (2012). A review of sediment and nutrient concentration data from Australia for use in catchment water quality models. Marine pollution bulletin, 65(4-9), 101-116.

Bayrak Yılmaz, G. (2011). Yüzey Sularında Uzun Süreli Besi Yüklerinin Etkisinin Belirlenmesi: Ergene Havzası Örneği. Doktora Tezi, 168s İstanbul Üniversitesi/Fen Bilimleri Enstitüsü, İstanbul.

Bayrak, G., Keleş, E., Ölmez, Z. (2019). Investigation of Green Infrastructure Applicationability in Edirne City Center. XIth International Sinan Symposium Proceedings Book, 11-12 April 2019, Trakya University Faculty of Architecture, Edirne.

Benedict, M. A., McMahon, E. T. (2002). Green infrastructure: smart conservation for the 21st century. Renewable resources journal, 20(3), 12-17.

Brown, R. A., Hunt III, W. F. (2011). Impacts of media depth on effluent water quality and hydrologic performance of undersized bioretention cells. Journal of Irrigation and Drainage Engineering, 137(3), 132-143.

Carpenter, D. D., Hallam, L. (2010). Influence of planting soil mix characteristics on bioretention cell design and performance. Journal of Hydrologic Engineering, 15(6), 404-416.

Center for Neighborhood Technology (CNT) (2010). The Value of Green Infrastructure A Guide to Recognizing Its Economic, Environmental and Social Benefits. 14.04.2021 tarihinde https://www.cnt.org/sites/default/files/publications/CNT Value-of-Green-Infrastructure.pdf adresinden erişildi.

Chen, X., Peltier, E., Sturm, B. S., \& Young, C. B. (2013). Nitrogen removal and nitrifying and denitrifying bacteria quantification in a stormwater bioretention system. Water Research, 47(4), 1691-1700. 
Chow, M. F., Yusop, Z., Shirazi, S. M. (2013). Storm runoff quality and pollutant loading from commercial, residential, and industrial catchments in the tropic. Environmental monitoring and assessment, 185(10), 8321-8331.

Davis A.P., McCuen R.H. (2005). Stormwater Management for Smart Growth, Springer US. Boston, MA. P368.

Davis, A. P. (2007). Field performance of bioretention: Water quality. Environmental Engineering Science, 24(8), 10481064.

Davis, A. P., Hunt, W. F., Traver, R. G., Clar, M. (2009). Bioretention technology: Overview of current practice and future needs. Journal of environmental engineering, 135(3), 109-117.

Davis, A. P., Shokouhian, M., Sharma, H., Minami, C. (2006). Water quality improvement through bioretention media: Nitrogen and phosphorus removal. Water Environment Research, 78(3), 284-293.

Davis, A. P., Shokouhian, M., Sharma, H., Minami, C.,Winogradoff, D. (2003). Water quality improvement through bioretention: Lead, copper, and zinc removal. Water Environment Research, 75(1), 73-82.

De Rozari, P., Greenway, M., El Hanandeh, A. (2018). Nitrogen removal from sewage and septage in constructed wetland mesocosms using sand media amended with biochar. Ecological Engineering, 111, 1-10.

Demir D. (2012). Konvansiyonel Yă̆mursuyu Yönetim Sistemleri ile Sürdürülebilir Yağmursuyu Yönetim Sistemlerinin Karşılaştırılması: İTÜ Ayazağa Yerleşkesi Örneği. Yüksek Lisans Tezi, 2s, İstanbul Teknik Üniversitesi/Fen Bilimleri Enstitüsü, İstanbul.

Dietz, M. E. (2007). Low impact development practices: A review of current research and recommendations for future directions. Water, air, and soil pollution, 186(1), 351-363.

Dietz, M. E., Clausen, J. C. (2006). Saturation to improve pollutant retention in a rain garden. Environmental science \& technology, 40(4), 1335-1340.

EEA (2020). 11.12.2020 tarihinde https://www.eea.europa.eu/themes/water/european-waters/water-use-andenvironmental-pressures adresinden erişildi.

Ely, M.,Pitman, S. D. (2014). Green Infrastructure: Life support for human habitats. The Compelling Evidence for Incorporating Nature into Urban Environments, Green Infrastructure project, Department of Environment, Water and Natural Resources, Botanic Gardens of South Australia.

Fisch, J. (2014). Green Infrastructure and the Sustainability Concept: A Case Study of the Greater New Orleans Urban Water Plan. Master's thesis: University of New Orleans.

Francey, M., Fletcher, T. D., Deletic, A., Duncan, H. (2010). New insights into the quality of urban storm water in Southeastern Australia. Journal of Environmental Engineering, 136(4), 381-390.

Geronimo, F. K. F., Maniquiz-Redillas, M. C., Kim, L. H. (2013). Treatment of parking lot runoff by a tree box filter. Desalination and water treatment, 51(19-21), 4044-4049.

Göbel, P., Dierkes, C., Coldewey, W. G. (2007). Storm water runoff concentration matrix for urban areas. Journal of contaminant hydrology, 91(1-2), 26-42.

Goh, H. W., Lem, K. S., Azizan, N. A., Chang, C. K., Talei, A., Leow, C. S., Zakaria, N. A. (2019). A review of bioretention components and nutrient removal under different climates-future directions for tropics. Environmental Science and Pollution Research, 26(15), 14904-14919.

Gülgün, B., Yazıcı, K. (2016). Yeşil Altyapı Sistemlerinde Mevcut Uygulamalar. Ziraat Mühendisleri Dergisi, (363), 33-39.

Hatt, B. E., Fletcher, T. D., Deletic, A. (2009). Hydrologic and pollutant removal performance of stormwater biofiltration systems at the field scale. Journal of Hydrology, 365(3-4), 310-321.

Hunt, W. F., Jarrett, A. R., Smith, J. T., Sharkey, L. J. (2006). Evaluating bioretention hydrology and nutrient removal at three field sites in North Carolina. Journal of Irrigation and Drainage Engineering, 132(6), 600-608.

Hunt, W. F., Smith, J. T., Jadlocki, S. J., Hathaway, J. M., Eubanks, P. R. (2008). Pollutant removal and peak flow mitigation by a bioretention cell in urban Charlotte, NC. Journal of Environmental Engineering, 134(5), 403-408. 
Jiang, C. B., Li, J. K., Zhang, B. H., Ruan, T. S., Li, H. E., Dong, W. (2018). Design parameters and treatment efficiency of a retrofit bioretention system on runoff nitrogen removal. Environmental Science and Pollution Research, 25(33), 33298-33308.

Jiang, C., Li, J., Li, H., Li, Y., Chen, L. (2017). Field performance of bioretention systems for runoff quantity regulation and pollutant removal. Water, Air, \& Soil Pollution, 228(12), 1-13.

Jotte, L., Raspati, G. Azrague, K. (2017). Review of stormwater management practices. Klima 2050 Report 7.

Trondheim, 2017. ISBN: 978-82-536-1545-5

Kloss, C., Calarusse, C., Stoner, N. (2006). Rooftops to rivers: Green strategies for controlling stormwater and combined sewer overflows. Natural Resources Defense Council, Washington D.C.

Kluge, B., Markert, A., Facklam, M., Sommer, H., Kaiser, M., Pallasch, M., Wessolek, G. (2018). Metal accumulation and hydraulic performance of bioretention systems after long-term operation. Journal of soils and sediments, 18(2), 431-441.

LeFevre, G. H., Paus, K. H., Natarajan, P., Gulliver, J. S., Novak, P. J., Hozalski, R. M. (2015). Review of dissolved pollutants in urban storm water and their removal and fate in bioretention cells. Journal of Environmental Engineering, 141(1), 04014050.

Li, L., Davis, A. P. (2014). Urban stormwater runoff nitrogen composition and fate in bioretention systems. Environmental science \& technology, 48(6), 3403-3410.

Liu, J., Davis, A. P. (2014). Phosphorus speciation and treatment using enhanced phosphorus removal bioretention. Environmental science \& technology, 48(1), 607-614.

Liu, J., Sample, D. J., Bell, C., Guan, Y. (2014). Review and research needs of bioretention used for the treatment of urban stormwater. Water, 6(4), 1069-1099.

Macnamara, J., Derry, C. (2017). Pollution removal performance of laboratory simulations of Sydney's street stormwater biofilters. Water, 9(11), 907.

Mangangka, I. R., Liu, A., Egodawatta, P., Goonetilleke, A. (2015). Performance characterisation of a stormwater treatment bioretention basin. Journal of environmental management, 150, 173-178.

McLeod, S. M., Kells, J. A., Putz, G. J. (2006). Urban runoff quality characterization and load estimation in Saskatoon, Canada. Journal of environmental engineering, 132(11), 1470-1481.

Nazahiyah, R. (2005). Modeling of non-point source pollution from residential and commercial catchments in Skudai, Johor. Master Thesis, University Technology Malaysia, Malaysia.

Passeport, E., Hunt, W. F., Line, D. E., Smith, R. A., Brown, R. A. (2009). Field study of the ability of two grassed bioretention cells to reduce storm-water runoff pollution. Journal of Irrigation and Drainage Engineering, 135(4), 505510 .

Peterson, M. A. (2016). The effect of the antecedent dry conditions on nitrogen removal for a modified bioretention system. Doctoral dissertation, University of South Florida.

Prince George's County, Maryland (PGCM). (2007). Bioretention Manual. Environmental Services Division; Department of Environmental Resources, Prince George's County: Upper Marlboro, MD, USA. Available online: https://www.princegeorgescountymd.gov/Government/AgencyIndex/DER/ESG/Bioretention/pdf/Bioretention\%20Ma nual_2009\%20Version.pdf.

Roseen, R. M., Ballestero, T. P., Houle, J. J., Avelleneda, P., Wildey, R., Briggs, J. (2006). Storm water low-impact development, conventional structural, and manufactured treatment strategies for parking lot runoff: Performance evaluations under varied mass loading conditions. Transportation research record, 1984(1), 135-147.

Shakouri N. (2016). Kentlerde Yağmursuyu Yönetimi Kapsamında Yeşil Altyapı peyzaj Planlama ve Tasarım Yaklaşımı: Sakarya-Hendek Örneği. Doktora Tezi, 27s. Ankara Üniversitesi/Fen Bilimleri Enstitüsü, Ankara.

Singh, R. P., Zhao, F., Ji, Q., Saravanan, J., Fu, D. (2019). Design and performance characterization of roadside bioretention systems. Sustainability, 11(7), 2040. 
Stephan, E. A., Endreny, T. A. (2016). Weighting nitrogen and phosphorus pixel pollutant loads to represent runoff and buffering likelihoods. JAWRA Journal of the American Water Resources Association, 52(2), 336-349.

Van der Tak, L., Edwards, C. (2001). An ArcView GIS tool to calculate nonpoint sources of pollution in watershed and stormwater projects. USEPA: Washington, DC, USA.

Wan, Z., Li, T., Liu, Y. (2018). Effective nitrogen removal during different periods of a field-scale bioretention system. Environmental Science and Pollution Research, 25(18), 17855-17861.

Wang, J., Chua, L. H., Shanahan, P. (2017). Evaluation of pollutant removal efficiency of a bioretention basin and implications for stormwater management in tropical cities. Environmental Science: Water Research \& Technology, $3(1), 78-91$.

Wrage, N., Velthof, G.L., van Beusichem, M.L., Oenema, O. (2001). Role of nitrifier denitrification in the production of nitrous oxide, Soil Biology and Biochemistry, 33(12-13), 1723-1732, ISSN 0038-0717, https://doi.org/10.1016/S0038-0717(01)00096-7.

Yang, Y. Y., \& Lusk, M. G. (2018). Nutrients in urban stormwater runoff: Current state of the science and potential mitigation options. Current Pollution Reports, 4(2), 112-127.

Zhang H, Ahmad Z, Shao Y, Yang Z, Jia Y, Zhong H. (2021). Bioretention for removal of nitrogen: processes, operational conditions, and strategies for improvement. Environmental Science and Pollution Research; 28(9):1051910535. doi: 10.1007/s11356-020-12319-1. Epub 2021 Jan 14. PMID: 33443738.

Zhou, Z., Li, H., Song, C., Cao, X., Zhou, Y. (2017). Prevalence of ammonia-oxidizing bacteria over ammonia-oxidizing archaea in sediments as related to nutrient loading in Chinese aquaculture ponds. Journal of Soils and Sediments, 17(7), 1928-1938. 